Ambiente \& Água - An Interdisciplinary Journal of Applied Science
ISSN 1980-993X - doi:10.4136/1980-993X
www.ambi-agua.net
E-mail: ambi-agua@agro.unitau.br

\title{
Characteristics of irrigation tube wells on major river flood plains in Bauchi State, Nigeria
}

\author{
doi: 10.4136/ambi-agua.1314
}

Received: 12 Feb. 2014; Accepted: 05 Sep. 2014

\author{
Abdullahi Abubakar Sadiq ${ }^{1 *}$; Sunusi Abubakar Amin ${ }^{1}$; Desa Ahmad ${ }^{2}$; \\ Baba Gana Umara ${ }^{3}$ \\ ${ }^{1}$ Abubakar Tafawa Balewa University (ATB), PMB 0248 Bauchi, Nigeria \\ Agricultural and Bioresource Engineering Department \\ ${ }^{2}$ Universiti Putra Malaysia, 43400 Selangor, DE, Malaysia \\ Department of Biological and Agricultural Engineering \\ ${ }^{3}$ University of Maiduguri, Nigeria \\ Department of Agricultural and Environmental Engineering \\ *Corresponding author: e-mail: asabdullahi@atbu.edu.ng, \\ sunusiabubakar@yahoo.com,desa@upm.edu.my, babazulum@yahoo.com
}

\begin{abstract}
Water for traditional irrigation on flood-plains in Bauchi State is obtained from the Jama'are, Gongola and Komadugu river systems. The plains are replenished during rainy season and farmers often drill wells to irrigate their farm lands. Wells are drilled by jetting techniques and most of the farmers' plots are less than 1 hectare. Well yield varies from 0.6 to $9.4 \mathrm{Ls}^{-1}$ and water is drawn from a depth of $12 \mathrm{~m}$. From the mean yield, the results indicate higher water abstraction from tube wells located at Jama'are flood plains. The study recommended appropriately locating wells and greater investment in extension services in order to facilitate the growth of farmer associations.
\end{abstract}

Keywords: Fadama, groundwater, Jama'are, NFDP, Savannah.

\section{Características de poços artesianos de irrigação das planícies de inundação dos principais rios no Estado de Bauchi, Nigéria}

\section{RESUMO}

A água para irrigação tradicional nas planícies de inundação no Estado de Bauchi é obtida a partir de sistemas fluviais Jama'are, Gongola e Komadugu. As planícies são recarregadas durante a estação chuvosa e os produtores rurais muitas vezes perfuram poços para irrigar suas terras. Os poços são perfurados usando-se técnicas de jateamento e os talhões irrigados são em sua maioria menores do que 1 ha. $O$ rendimento dos poços varia de 0,6 a 9,4 $\mathrm{Ls}^{-1}$ e a água é obtida a uma profundidade de $12 \mathrm{~m}$. A partir do rendimento médio, os resultados indicam maior captação de água em poços tubulares localizados nas planícies de inundação do Jama'are. O estudo recomenda a adequada implantação dos poços e a ampliação do serviço de extensão para facilitar o crescimento das associações de produtores.

Palavras-chave: águas subterrâneas, Fadama, Jama'are, NFDP, Savana. 


\section{INTRODUCTION}

Agriculture is the economic mainstay of most rural households in Nigeria and is a significant sector in the Nigerian economy. The important benefits of the agricultural sector to Nigeria's economy include: provision of food, contribution to the gross domestic product (GDP), provision of employment, provision of raw materials to agro-allied industries and generation of foreign exchange. Indeed, the rural sector employs nearly half of the country's labor force and accounts for up to 5\% of its total exports (Yahaya, 2002).

Unfortunately, these areas are also home to more than $70 \%$ of the nation's poor. Income and productivity in rural areas are stagnant and low. Farming practices are predominantly at the subsistence level and depend on the vagaries of weather for most of the year. Crop growth is limited by soil salinity and water scarcity, especially in areas with shallow groundwater. The water flowing upward from the groundwater into the root-zone plays an important role by contributing to the water needs of plants in the presence of shallow water tables (Xie et al., 2011).

With abundant land and water resources, the Nigerian agricultural sector has a high potential for growth. This prompted the federal government to institute several plans and programs to enhance the country's agricultural productivity. Some of these programs include the National Accelerated Food Production Program, Operation Feed the Nation, Green Revolution and, of course, the National Fadama Projects (BSADP, 2007). The most recent of these efforts is the National Fadama Development Program (NFDP). The Fadama Irrigation plan is one of the World Bank assisted programs that operated between 1993 and 2010.

The total irrigation potential in Nigeria is estimated at 2.0 million hectare, of which less than 900,000 hectares are currently under irrigation. An estimated $70 \%$ of this potential is in the northern part of the country and about $20 \%$ in the humid south, with the balance in the highland areas of central and western Nigeria. Fadama lands account for about 0.94 million hectares of this potential irrigable land (Takeshima et al., 2010).

Bauchi participated in both NFDP I and II. Farmers often drill shallow wells in the fadama areas for irrigation. Replenishment for these wells is either from the Jama'are, Gongola or Komadugu river systems. Farmers often drill their wells with the aim of maximizing production and thereby generating greater revenue by bringing more land under production. This is often done with no consideration to the inherent pumping capacity of the well, which may subject the wells to excessive pressure through over-extraction. This practice has an adverse effect on the ecosystem.

Accordingly, many studies have shown that irrigation systems are not used as their designers had intended (Ahmad et al., 2009; Kumar et al., 2010). This study investigated some of the characteristics of tube wells on two river system flood-plains.

\section{MATERIALS AND METHODS}

\subsection{Study Area}

The study was conducted in 2007 in eleven of twenty Local Government Areas (LGA's) of Bauchi State, Nigeria. A total of twenty-four villages were considered from the North, South and Central Senatorial zones (Figure 1).

Topographically, Bauchi State is generally divided into two main vegetation zones: the Sudan Savannah in the North and the Sahel Savannah in the South and East. Annual rainfall is about $700 \mathrm{~mm}$ in the Sudan Savannah zone and about $1300 \mathrm{~mm}$ in the Sahel Savannah. 


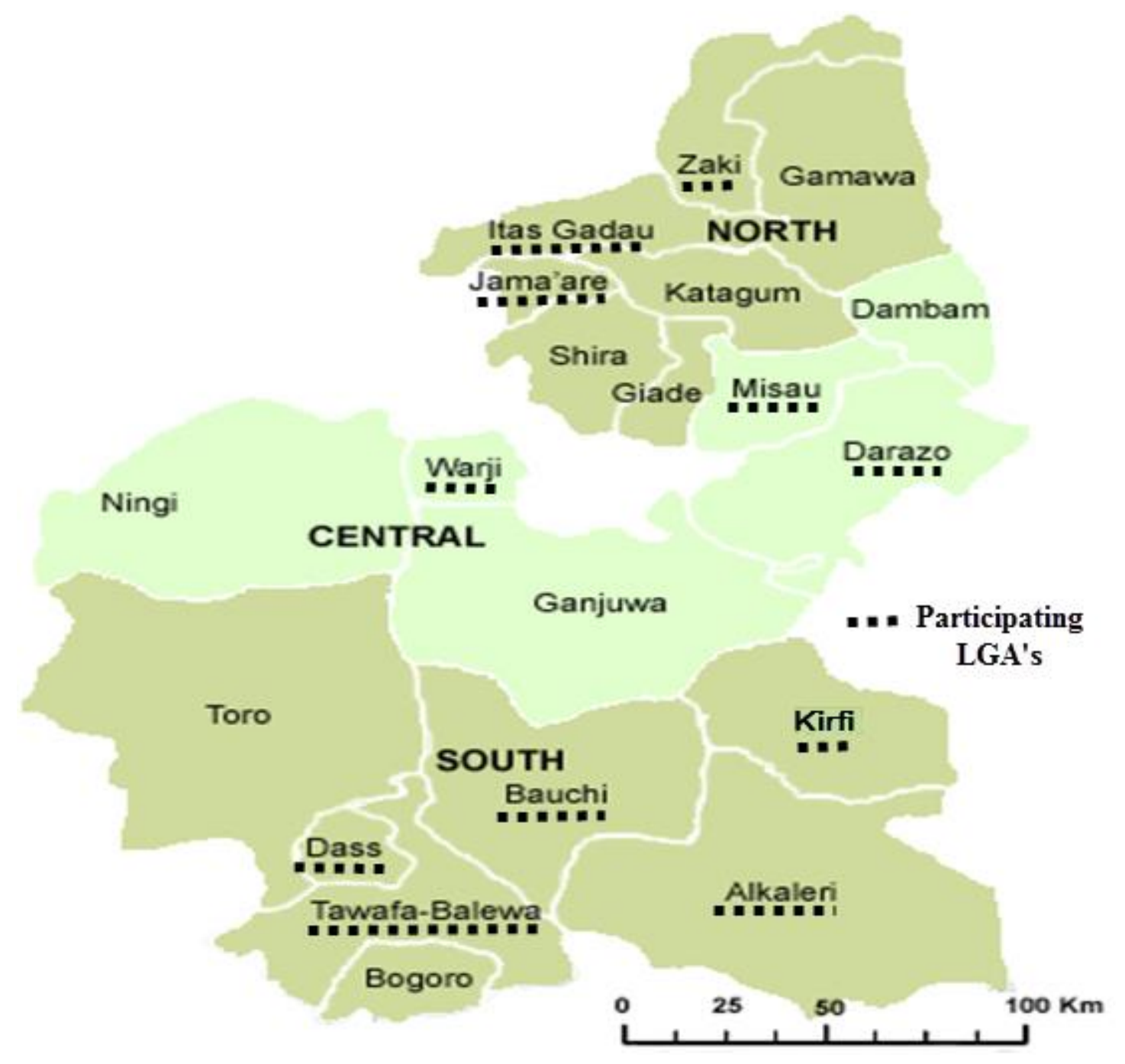

Figure 1. Study locations from Eleven Local Government Areas in Bauchi State. source: Adapted from Google Maps.

The state is located between longitude $8^{\circ} 45^{\prime \prime}$ and $11^{\circ} 45 \mathrm{E}$, and latitude $9^{\circ} 30^{\prime \prime}$ and $12^{\circ} 30^{\prime \prime} \mathrm{N}$. It covers a total land area of $49,259.01 \mathrm{~km}^{2}$ representing $5.3 \%$ of Nigeria's total land. Bauchi State is bordered by seven states, Kano and Jigawa States to the North, Gombe and Yobe States to the East, Taraba and Plateau States to the South and Kaduna State to the West. The climate of the state is generally tropical, with distinct wet and dry seasons. Rainfall in the State shows a marked variation between $1300 \mathrm{~mm}$ per year in the south and only 700 mm per year in the extreme north (BSADP, 2007). Rainfall is concentrated in a short wet season which extends from May to October, while the dry season lasts more than 5 months (with no rain whatsoever). The periods of the wet and dry seasons may vary depending on the prevailing winds blowing across the country at different times of the year.

\subsection{Fadama lands}

"Fadama" are flood plains and low lying areas underlined by shallow aquifers found along Nigeria's river system (World Bank, 2001). These river valley areas are seasonally flooded or that have high water tables for all or most of the year. Fadama irrigation is an ageold tradition in the Nigerian Hausa land, and the season flooding of the valley's bottom allows for the growth of a variety of crops with small-scale irrigation (Yahaya, 2002).

The National Fadama Development Program (NFDP) was designed to assist some of the Federation's States through the World Bank-supported Agricultural Development Program 
(ADP) network. The assistance varies, but may include: financing the provision of shallow tube wells in Fadama lands for small-scale irrigation; simplifying drilling technologies for shallow tube wells; constructing Fadama infrastructure; organizing Fadama farmers for irrigation management, cost recovery and better access to credit, marketing and other services; and the provision of vehicles, pumps and other equipment (Ayanwale and Alimi, 2004).

More specifically, the government's involvement in NFDP and the National Program of Food Security (NPFS) has consisted mostly of providing financial assistance to farmers for acquiring irrigation equipment, to include pumps, tube wells and wash bores (Takeshima et al., 2010).

\subsection{River systems in Bauchi State}

There are three river systems connected to Bauchi State: the Gongola, the Jama'are and the Komadugu. The Gongola River crosses Bauchi State in the Tafawa Balewa Local Government Area in the south and in the Kirfi and Alkaleri Local Government Areas in the east, while the Jama'are River cuts across a number of Local Government Areas in the north.

Moreover, a substantial part of the Hadeja-Jama'are River Basin lies in Bauchi State, which along with various fadama (floodplain) areas in the state provides suitable land for agriculture. Irrigation and grazing along the flood plains (Fadama lands) occur throughout the dry season. Tube wells are replenished mainly from these river systems. In addition to rainfall, Bauchi State receives water from a number of minor rivers (Figure 2). These small rivers are mainly concentrated in the northern part of the State, located at $11^{0} 40^{\prime} \mathrm{N}, 09^{0} 56^{\prime} \mathrm{E}$.

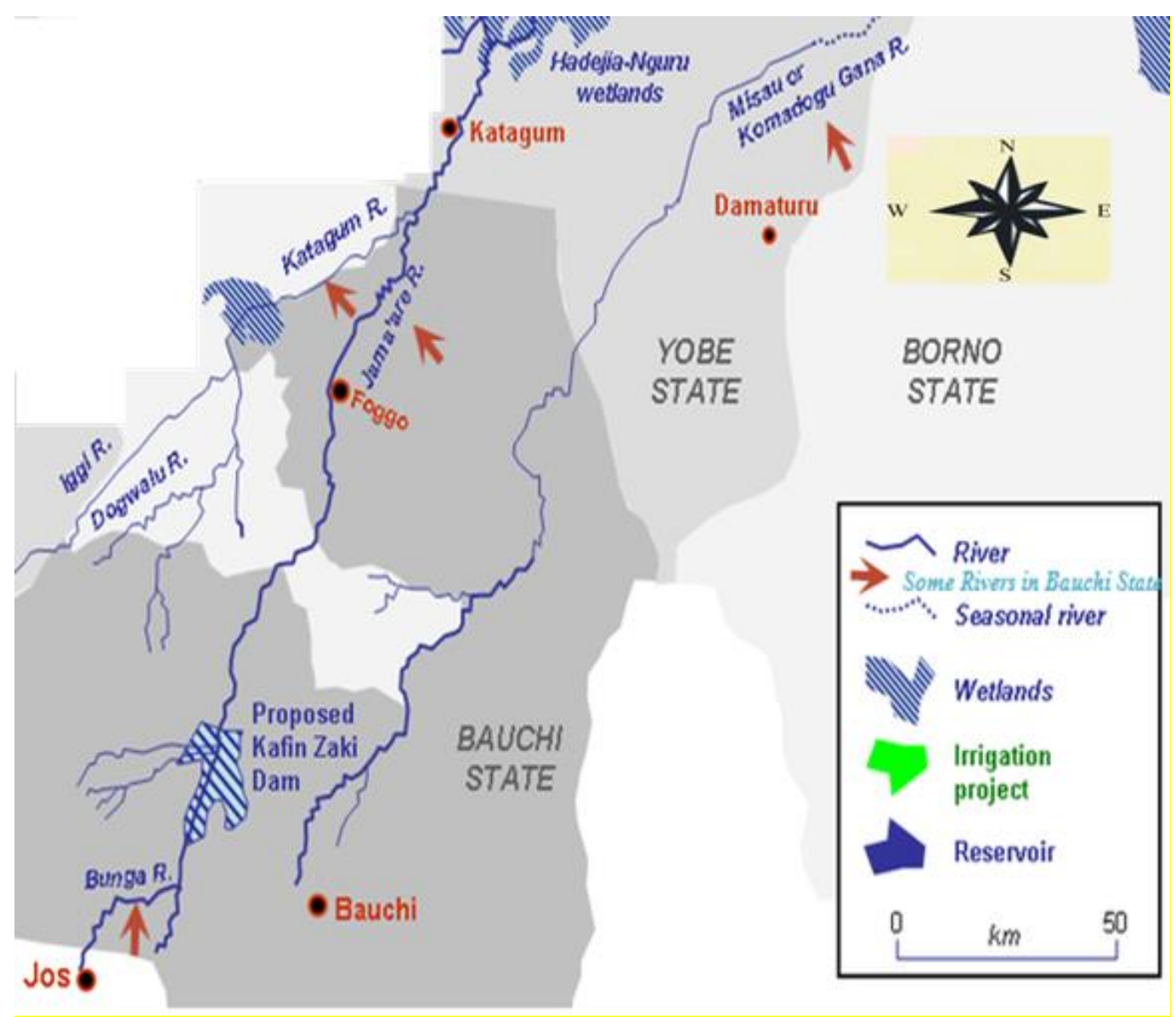

Figure 2. The Komadugu, Jama'are, Katagum and Bunga Rivers in the Northern part of Bauchi State.

Source: Adapted from Google Maps. 
In this study, twenty-five tube wells were selected from the Jama'are and the Gongola River floodplains, 10 and 15 wells respectively. Well parameters such as location, static water level, depth, and discharge were recorded. Tube well recovery was measured during the test pumping. A comparison was done on well performance based on the well's location and the river system.

\section{RESULTS AND DISCUSSION}

Table 1 indicates the characteristics (static water table, well depth, well discharge and well recovery) of tube wells on the Jama'are river system floodplain. The wells' yields are in the range of 0.5 to $6.0 \mathrm{~L} \mathrm{~s}^{-1}$ and water is obtained at a depth of up to $12 \mathrm{~m}$. Several factors may attribute to well performance, most importantly the climatic condition of Local Government Areas. Wells located in the northern part of the State have a limited annual rainfall of $<400$ $\mathrm{mm}$ /annum, while those in the southern part record up to $700 \mathrm{~mm} /$ annum.

Table 1. Irrigation well characteristics of the Jama'are River Floodplain.

\begin{tabular}{|c|c|c|c|c|c|c|}
\hline $\begin{array}{l}\text { Local Govt. } \\
\text { Area }\end{array}$ & Village Name & Well Coordinates & $\begin{array}{c}\text { Static Water } \\
\text { Level (m) }\end{array}$ & $\begin{array}{l}\text { Well Depth } \\
\text { (m) }\end{array}$ & $\begin{array}{c}\text { Discharge, } \\
\mathbf{Q}\left(\mathbf{L} \mathbf{s}^{-1}\right)\end{array}$ & $\begin{array}{c}\text { Recovery, } \mathrm{R} \\
(\%)\end{array}$ \\
\hline \multirow[t]{2}{*}{ Itas Gadau } & Kashuwa & $\begin{array}{l}11^{0} 45^{\prime} 18.5^{\prime \prime} \mathrm{N} \\
09^{0} 58^{\prime \prime} 45.4^{\prime \prime} \mathrm{E}\end{array}$ & 2.32 & 5.05 & 4.85 & - \\
\hline & Gadau & $\begin{array}{l}11^{0} 53,06.5^{\prime \prime} \mathrm{N} \\
10^{0} 0823.9^{\prime \prime} \mathrm{E}\end{array}$ & 3.22 & 12.5 & 4.12 & - \\
\hline \multirow[t]{3}{*}{ Jama'are } & Dogonjeji & $\begin{array}{l}11^{0} 44^{\prime} 40.9^{\prime \prime} \mathrm{N} \\
09^{0} 5845.5^{\prime \prime} \mathrm{E}\end{array}$ & 2.73 & 7.53 & 5.54 & - \\
\hline & Jama'are & $\begin{array}{l}11^{0} 4004.3^{\prime \prime} \mathrm{N} \\
09^{0} 56^{\prime} 44.4^{\prime \prime} \mathrm{E}\end{array}$ & 3.66 & 7.05 & 6.05 & - \\
\hline & Yerima & $\begin{array}{l}11^{0} 17^{\prime} 17.9^{\prime \prime} \mathrm{N} \\
10^{0} 28^{\prime} 11.0^{\prime \prime} \mathrm{E}\end{array}$ & 5.55 & 8.84 & 0.45 & 73 \\
\hline \multirow[t]{2}{*}{ Shira } & Ganuwa & $\begin{array}{l}11^{0} 37^{\prime} 56.5^{\prime \prime} \mathrm{N} \\
09^{0} 566^{\prime} 43.3^{\prime \prime} \mathrm{E}\end{array}$ & 2.97 & 8.35 & 4.44 & - \\
\hline & Disina & $\begin{array}{l}11^{0} 3012.5^{\prime \prime} \mathrm{N} \\
09^{0} 55^{\prime} 49.9^{\prime \prime} \mathrm{E}\end{array}$ & 3.72 & 7.28 & 5.12 & - \\
\hline Warji & Disa & $\begin{array}{l}11^{0} 05^{\prime} 49.9^{\prime \prime} \mathrm{N} \\
09^{0} 3941.4^{\prime \prime} \mathrm{E}\end{array}$ & 2.64 & 6.35 & 4.80 & 90 \\
\hline \multirow[t]{2}{*}{ Zaki } & Katagum & $\begin{array}{l}12^{0} 17^{\prime} 10.4^{\prime \prime} \mathrm{N} \\
10^{0} 21,52.5^{\prime \prime} \mathrm{E}\end{array}$ & 5.62 & 11.6 & 1.50 & 72 \\
\hline & Chibiyayi & $\begin{array}{l}11^{0} 599^{\prime} 47.5^{\prime \prime} \mathrm{N} \\
10^{0} 11^{\prime} 50.2^{\prime \prime} \mathrm{E}\end{array}$ & 4.82 & 12.23 & 2.32 & - \\
\hline Mean & & & 3.73 & 8.68 & 3.92 & \\
\hline
\end{tabular}

The Jama'are is a source of replenishment for minor rivers in the northern part of the state (Figure 3). Wells are drilled to a depth of about $8 \mathrm{~m}$ and the high yield $\left(4.0 \mathrm{~L} \mathrm{~s}^{-1}\right)$ has attracted more farmers and herdsmen to the area. The study also found that most villages near the rivers are involved in irrigation for subsistence during the dry season. 
Table 2 is the result of tube well parameters in eastern and southern parts of Bauchi State. Yields of wells are between 1.6 to $9.4 \mathrm{~L} \mathrm{~s}^{-1}$ and water is available at a depth of $10 \mathrm{~m}$ (Figure 3).

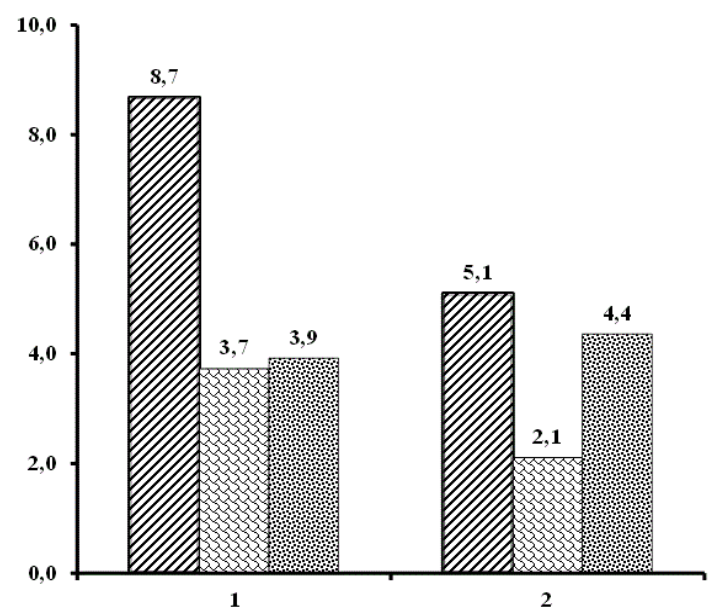

Figure 3. Mean.depth, Static water level (m) and Discharge $\left(\mathrm{Ls}^{-1}\right)$ of Tube wells on Floodplains.

Table 2. Irrigation well characteristics of the Gongola River Floodplain.

\begin{tabular}{|c|c|c|c|c|c|c|}
\hline $\begin{array}{l}\text { Local Govt. } \\
\text { Area }\end{array}$ & $\begin{array}{l}\text { Village } \\
\text { Name }\end{array}$ & Well Coordinates & $\begin{array}{c}\text { Static } \\
\text { Water } \\
\text { Level }(\mathbf{m})\end{array}$ & $\begin{array}{c}\text { Well } \\
\text { Depth (m) }\end{array}$ & $\begin{array}{c}\text { Discharge, } Q \\
\quad\left(\mathrm{~L} \mathrm{~s}^{-1}\right)\end{array}$ & $\begin{array}{c}\text { Recovery, R } \\
(\%)\end{array}$ \\
\hline \multirow[t]{3}{*}{ Alkaleri } & Fanti & $\begin{array}{l}10^{0} 03,51.1 " \mathrm{~N} \\
10^{0} 16^{\prime} 41.5^{\prime \prime} \mathrm{E}\end{array}$ & 2.06 & 2.68 & 1.66 & 100 \\
\hline & Duguri & $\begin{array}{l}10^{0} 16,19.9 ” \mathrm{~N} \\
09^{0} 48^{\prime} 02.4 ” \mathrm{E}\end{array}$ & 1.80 & 4.84 & 4.40 & - \\
\hline & Mainamaji & $\begin{array}{l}10^{0} 03,56.2 ” \mathrm{~N} \\
10^{0} 18^{\prime} 00.5 " \mathrm{E}\end{array}$ & 2.23 & 5.25 & 6.3 & 82 \\
\hline \multirow[t]{2}{*}{ Bauchi } & Zungur & $\begin{array}{l}09^{0} 58^{\prime} 44.7 " \mathrm{~N} \\
09^{0} 46^{\prime} 31.8^{\prime \prime} \mathrm{E}\end{array}$ & 3.3 & 5.93 & 5.40 & - \\
\hline & Zungur & $\begin{array}{l}09^{0} 58^{\prime} 50.3^{\prime \prime} \mathrm{N} \\
09^{0} 46^{\prime} 40.6^{\prime \prime} \mathrm{E}\end{array}$ & 2.73 & 3.06 & 4.30 & - \\
\hline \multirow[t]{3}{*}{ Dass } & Bagel & $\begin{array}{l}10^{0} 02 \\
09^{0} 36.35 .3^{\prime} 25.8^{\prime \prime} \mathrm{E}\end{array}$ & 3.00 & 6.00 & 5.47 & - \\
\hline & Kagadama & $\begin{array}{l}10^{0} 10,13.0 " \mathrm{~N} \\
09^{0} 33,59.11 \mathrm{E}\end{array}$ & 1.89 & 3.78 & 6.20 & 71 \\
\hline & Wandi & $\begin{array}{l}09^{0} 58,52.2^{\prime \prime} \mathrm{N} \\
09^{0} 30,19.8^{\prime \prime} \mathrm{E}\end{array}$ & 3.00 & 6.93 & 1.82 & 75 \\
\hline Darazo & Tauya & $\begin{array}{l}09^{0} 46^{\prime} 42.0^{\prime \prime} \mathrm{N} \\
10^{0} 33^{2} 22.4^{\prime \prime} \mathrm{E}\end{array}$ & 2.34 & 5.96 & 2.79 & 88 \\
\hline \multirow[t]{3}{*}{ Kirfi } & Badara & $\begin{array}{l}10^{0} 21^{\prime} 25.5^{\prime \prime} \mathrm{N} \\
10^{0} 20^{\prime} 09.1^{\prime \prime} \mathrm{E}\end{array}$ & 2.81 & 4.08 & 2.08 & 87 \\
\hline & Bara & $\begin{array}{l}10^{0} 21^{\prime} 33.0^{\prime \prime} \mathrm{N} \\
10^{0} 46^{\prime} 18.7^{\prime \prime} \mathrm{E}\end{array}$ & 0.65 & 2.4 & 2.10 & - \\
\hline & Boli & $\begin{array}{l}10^{0} 32^{\prime} 47.4^{\prime \prime} \mathrm{N} \\
10^{0} 27^{\prime} 11.0^{\prime \prime} \mathrm{E}\end{array}$ & 1.72 & 9.43 & 9.43 & - \\
\hline \multirow[t]{3}{*}{$\begin{array}{l}\text { Tafawa } \\
\text { Balewa }\end{array}$} & Burwat & $\begin{array}{l}09^{0} 49^{\prime} 04.3^{\prime \prime} \mathrm{N} \\
09^{0} 51^{\prime} 15.4^{\prime \prime} \mathrm{E}\end{array}$ & 1.72 & 6.84 & 4.85 & - \\
\hline & Dajin & $\begin{array}{l}10^{0} 01,37.9^{\prime \prime} \mathrm{N} \\
09^{0} 38^{\prime} 25.6^{\prime \prime} \mathrm{E}\end{array}$ & 1.03 & 5.35 & 6.10 & - \\
\hline & Gori & $\begin{array}{l}09^{0} 51,36.1 " \mathrm{~N} \\
09^{0} 26^{\circ} 10.6^{\prime \prime} \mathrm{E}\end{array}$ & 1.28 & 3.97 & 2.40 & 77 \\
\hline Mean & & & 2.29 & 5.36 & 4.59 & \\
\hline
\end{tabular}


These sites have a shallower static water level $(2-7 \mathrm{~m})$ compared to wells on other floodplains in the state. The average depth and yield from all the study locations was 5.4 to $8.7 \mathrm{~m}$ and $4.6 \mathrm{~L} \mathrm{~s}^{-1}$ respectively.

\section{CONCLUSIONS}

The study revealed that tube wells along the floodplains are replenished by the Jama'are and the Gongola river systems. All of the pumping tests indicated a high yield recovery percentage. A yield recovery of $71-100 \%$ was obtained from some wells during the study. From a water conservation perspective, groundwater irrigation may be most favorable on a small-scale level. Many farmers prefer groundwater for the flexibility it allows in irrigation, among other reasons.

Since groundwater is accessible to many farmers and does not always require collective action, less capital and planning is required for implementation as compared to large gravity irrigation projects (Kazmi et al., 2012).

Appropriate well location is essential in such a small holder irrigation plan. This will promote the longevity of well usage despite a growing population in the state. Extension services will promote the cooperation of farmers so that water user groups (WUG), irrigation associations, and other useful organizations may be established

\section{REFERENCES}

AHMAD, M. D.; TURRAL, H.; NAZEER, A. Diagnosing irrigation performance and water productivity through satellite remote sensing and secondary data in a large irrigation system of Pakistan. Agricultural Water Management v. 96, p. 551-564, 2009. http://dx.doi.org/10.1016/j.agwat.2008.09.017

AYANWALE A. B.; ALIMI, T. The impact of the National Fadama facility in alleviating rural poverty and enhancing agricultural development in south-western Nigeria. Journal of Social Sciences, v. 9, n. 3, p. 157-161, 2004.

BAUCHI STATE AGRICULTURAL DEVELOPMENT PROGRAMME - BSADP. Bauchi state Fadama III project environmental baseline survey. 2007. Available in: http://www.fadama.net/html/index.php. Access: 13 Jan. 2014.

KAZMI, I. S.; ERTSENA, M. W.; ASI, M. R. The impact of conjunctive use of canal and tube well water in Lagar irrigated area, Pakistan. Physics and Chemistry of the Earth, v. 47-48, p. 86-98, 2012. http://dx.doi.org/10.1016/j.pce.2012.01.001.

KUMAR, R.; SHUKLA, N.; NIGAM, D. P.; VERMA, V. K. Modernizing Sarda Sahayak canal system: the Masscote approach. Irrigation and Drainage, v. 59, p. 53-75, 2010. http://dx.doi.org/10.1002/ird.554

TAKESHIMA, H.; ADEOTI, A.; OKOLI, S.; SALAU, S.; RHOE, V. Demand characteristics for small-scale private irrigation technologies: knowledge gaps in Nigeria. Abuja: IFPRI, 2010. (Working Paper, n. 0018).

WORLD BANK. Nigeria National Fadama development program II: proposal for Project Development Fund (PDF), Block B Grant. 2001. Available in: www.gefonline.org. Access: 13 Jan. 2014. 
XIE, T.; LIU, X.; SUN, T. The effects of groundwater table and flood irrigation strategies on soil water and salt dynamics and reed water use in the Yellow River Delta, China. $\begin{array}{llllll}\text { Ecological Modelling, } & \text { v. 222, } & \text { p. }\end{array}$ http://dx.doi.org/10.1016/j.ecolmodel.2010.01.012

YAHAYA, M. K. Development and challenges of Bakolori irrigation project in Sokoto State, Nigeria. Nordic Journal of African Studies, v. 11, n. 3, p. 411-430, 2002. 